\section{References}

Cantarow, A., and Trumper, M. (1944). Lead Poisoning, p. 157. Williams and Wilkins, Baltimore.

Davies, M. H. (1971). The monitoring and control of industrial exposure to lead. Trans. Soc. occup. Med., 21, 126.

Emmerson, B. T. (1967). In Renal Disease, edited by D. A. K. Black, 2nd ed., pp. 561-579. Blackwell, Oxford.

Hopkins, A. (1970). Experimental lead poisoning in the baboon. Brit. J. industr. Med., 27, 130-140.
Lane, R. E. (1951). Lead poisoning. In The British Encyclopaedia of Medical Practice, edited by Lord Horder, 2nd ed., vol. 8, pp. 15-23. Butterworth, London.

Scott, T. S. (1967). Industrial medicine-an art or a science? Brit. J. industr. Med., 24, 85-92.

Received for publication January 22, 1972.

\title{
Glaucopsia-blue-grey vision
}

\author{
W. T. JONES and M. D. KIPLING \\ Information and Advisory Service, TUC Centenary Institute of Occupational Health, \\ London School of Hygiene and Tropical Medicine, and the Department of Employment
}

\begin{abstract}
Jones, W. T., and Kipling, M. D. (1972). Brit. J. industr. Med., 29, 460-461. Glaucopsia-bluegrey vision. Blue-grey vision due to the effect of certain amines on the eye is a recognized but generally little known phenomenon. We review previous accounts of the condition and describe our experience of its occurrences. We consider the condition should be known as 'glaucopsia'.
\end{abstract}

\section{Historical review}

At a meeting of the British Chemical Manufacturers, Amor (1949) drew attention to a blue haze caused by ethylamines in a Table illustrating the toxicity of solvents. This reference was later included in the Industrial Hazards Bulletin in Ethylamines of Imperial Chemical Industries Ltd. Mastromatteo (1965) found that in several places in Ontario, where morpholine, ethyl morpholine, methyl morpholine, and other heterocyclic amines were used as catalysts, the workers suffered from a condition described as 'halo', 'blue haze', or 'foggy vision'. In one workplace where recently foamed material was stored, all the workers were affected, the effect being particularly noticeable at the end of the shift. The author considered that the condition was not serious except inasmuch as it interfered with driving home after work. He attributed the condition to oedema of the cornea. Dernehl (1966) described blue haze as occurring in the vision of amine and foam plastic manufacturers, and Munn (1967) reported that he had seen cases caused by tertiary octylamine as well as diethylamine. In animal experiments, monobutylamine (Hanzlik, 1923), diisopropylamine (Treon, Sigmon, Kitzmiller, and Heyroth, 1949), and monoethylamine, diethylamine, and triethylamine, the latter three in concentrations of vapour as low as $50 \mathrm{ppm}$, were found to be irritants (Brieger and Hodes, 1951). Mellerio and Weale (1966) found that the instillation of n-ethyl piperidine, $n$-methyl morpholine, n-ethyl morpholine, tetramethyl ethylenediamine, and di-methylamine caused a haziness, irregularity, and sloughing of the corneal surface with violent desiccation. S. L. Miles (personal communication), by holding ethylamines below his eye, was able to produce on himself the effect that the atmosphere was full of blue cigarette smoke. One 
of us produced a grey haziness by the same method with ethyl piperidine and methyl morpholine but was unable to reproduce the effect by inhaling the vapours.

\section{Pathology}

In this country ophthalmological examination of a group of workers who had suffered but recovered from the condition failed to reveal any ocular abnormalities though when the condition was produced experimentally the ophthalmologist reported that the pupil appeared obscured. No other abnormality was seen. Dernehl (1966) found a diffuse cloudiness which obscured the normal markings of the iris and with slit-lamp examination a diffuse corneal oedema with tiny vesicular collections of fluid in workers suffering from glaucopsia. Mellerio and Weale (1966) attributed the occurrence of glaucopsia to the Tyndall effect produced by denaturation of the proteins of the corneal epithelium. Munn (1967), however, considers that instillation of a liquid amine-an alkaline fluid-into the eye may not be exactly comparable to exposure to vapour only.

\section{Occupational exposures}

We have investigated cases occurring in the manufacture of amines and in the production of foam plastics, but we have also seen cases arising from the use of amines in a cold curing process in a foundry.

In one chemical works a fluctuating number of employees, between 3 and 18 men at various times, who had been exposed to a variety of amines at intervals over several years, complained of varying degrees of glaucopsia. Blue vision, grey vision, and haloes were most frequently noticed but always towards the end of the working day. One frequent complaint was that the phenomenon was particularly noticeable when driving a car. A range of amines and their intermediates had been manufactured at different times. These included morpholine, methyl morpholine, ethyl morpholine, other heterocyclic amines, and piperidines. The vision effects usually appeared between 30 and 90 minutes after exposure, which occurred when the batch process was complete and the chemicals were being withdrawn and packed. They lasted for four to six hours after leaving work. There were no other subjective complaints, no conjunctival irritation, and no epiphora. Few objective clinical observations were possible. The subjective effects were transitory and familiar to the workers, and few of them could be persuaded to delay departure from work for detailed examination. Mild conjunctival injection was observed in a minority. No corneal oedema or alteration in visual acuity was detectable by inspection or by ophthalmoscopy. It was observed that the lower molecular weight amines tended to produce a preponderance of blue vision and the higher amines produced grey vision. No permanent sequelae were detected in any of the employees exposed. No measurements of atmospheric concentrations of the offending substances were available.

\section{Discussion}

Experience has shown that exposure to certain amines may cause glaucopsia. The effect in those who are unaware of the possibility may cause alarm. As the use of amines is widespread we think that doctors working in industry should be aware of its existence.

\section{Nomenclature}

The terms xanthopsia, erythropsia, chromatopsia, cyanopsia, and xanthocyanopsia have been used to describe varieties of coloured vision. We suggest that this condition of blue-grey vision should be called glaucopsia as the Greek word 'glaucos' means blue-grey and was an adjective used to describe the eye. The epithet 'glaucopsis' is constantly used by Homer for the Goddess Athene. Most translators have baulked at describing her either blue- or greyeyed and with poetic licence used such phrases as 'bright-eyed Athene'-perhaps correctly, because in Homeric times the word did denote a flashing quality.

We are grateful to Dr T. A. Lloyd Davies for his encouragement, and to Dr E. L. Knowles, Dr G. MacBain. and Mr L. S. Miles who produced blue vision experimentally and also provided tears for further experimental work.

\section{References}

Amor, A. J. (1949). The toxicity of solvents. Manufacturing Chemist, 20, 540-544.

Brieger, H., and Hodes, W. A. (1951). Toxic effects of exposure to vapors of aliphatic amines. Arch. industr. Hyg., 3, 287-291.

Dernehl, C. U. (1966). Health hazards associated with polyurethane foams. J. occup. Med., 8, 59-62.

Hanzlik, P. J. (1923) Toxicity and action of the normal butylamins. J. Pharmacol. exp. Ther., 20, 435-449.

Mastromatteo, E. (1965). Recent occupational health experiences in Ontario. J. occup. Med., 7, 502-511.

Mellerio, J., and Weale, R. A. (1966). Hazy vision in amine plant operators. Brit. J. industr. Med., 23, 153-154.

Munn, A. (1967). Health hazards in the chemical industry. Trans. Soc. occup. Med., 17, 8-14.

Treon, J. F., Sigmon, H., Kitzmiller, K. V., and Heyroth, F. F. (1949). The p'ysiological response of animals to respiratory exposure to the vapors of diisopropylamine. J. industr. Hyg., 31, 142-145.

Received for publication February 11, 1972. 